\title{
MANAGEMENT ZONATION AND ITS IMPLEMENTATION AT A UNESCO WORLD HERITAGE SITE - A CASE STUDY FOR THE PLITVICE LAKES NATIONAL PARK, CROATIA
}

\author{
MAJA VURNEK ${ }^{1, *}$, ANDRIJANA BROZINČEVIĆ ${ }^{1}$, ŽELJKO RENDULIĆ1, \\ KAZIMIR MICULINIĆ ${ }^{1}$, VESNA VUKADIN ${ }^{2}$, and OGNJEN ŠKUNCA ${ }^{3}$
}

\author{
${ }^{1}$ Dr Ivo Pevalek Scientific Research Centre, Plitvice Lakes National Park, Josipa Jovića 19, 53231 Plitvice Lakes, Croatia \\ ${ }^{2}$ Park Bureau Ltd, Klanjčić 7A, 10000 Zagreb, Croatia \\ ${ }^{3}$ Granulum Salis Ltd, 3. Bijenički ogranak 13, 10000 Zagreb, Croatia \\ *Corresponding author: maja.vurnek@np-plitvicka-jezera.hr
}

\section{ABSTRACT}

Plitvice Lakes National Park (PLNP) is the oldest protected area in Croatia (since 1949) and was placed on the UNESCO World Heritage List in 1979. It is an area of outstanding universal value consisting of a freshwater ecosystem of 16 lakes divided by tufa barriers. Recently, this area has experienced pressure from visitors and significant infrastructural development. When the previous Management Plan expired in 2017, the PLNP initiated and adopted a new Management Plan. This involved the zonation of management in order to better conserve and use this protected area. Management zonation was based on spatial and other data on the distributions of the species and habitats (Natura 2000 and others); cultural values and geo-localities; visitor experiences; existing and planned infrastructure and settlements. Visitor classes and zones were determined using the Recreation Opportunity Spectrum (ROS) methodology. The new management zonation resulted in an increase of $13.9 \%$ in the area of the Park included in the Strict Conservation Zone, while succession and habitat degradation resulted in a decrease in the area of the Park in the Active Management Zone, especially in terms of grassland. Six ROS classes were defined. The established ROS classes and the new management zonation were interconnected, each reflecting the need to manage the protected area in terms of conserving its specific biodiversity and geodiversity, while offering visitors various experience opportunities and meeting the needs of the local community.

Keywords: management plan; Plitvice Lakes National Park; protected area; ROS classes; visitor pressure; zonation

\section{Introduction}

A protected area is "a clearly defined geographical space, recognised, dedicated and managed, through legal or other effective means, to achieve the long-term conservation of nature with associated ecosystem services and cultural values" (Dudley 2008). All protected areas should aim to conserve the composition, structure, function and evolutionary potential of biodiversity and contribute to regional conservation strategies (Dudley 2008). Based on the latest updates on the World Database on Protected Areas (WDPA), there are a total of 242,843 protected areas in 245 countries and territories (WDPA 2019). The coverage of terrestrial protected areas is $14.9 \%$, while that of marine areas was $16.8 \%$ in national waters in 2018 (Belle et al. 2018). According to the Croatian Nature Conservation Act (Official Gazette 80/13; $15 / 18$ ) there are nine protected areas that mainly accord with the IUCN categories. The Republic of Croatia has 408 protected areas, which cover $8.54 \%$ of the total surface of this country (CAEN 2019).

The national parks (category II) are large natural or near natural areas set aside to protect large-scale ecological processes, along with the complement of species and ecosystems characteristic of the area, which also provide a foundation for environmentally and culturally compatible spiritual, educational, recreational and visitor op- portunities. Among many other objectives, they include the management of use by visitors and most importantly the management of the area in order to maintain the area in as natural a state as possible (Dudley 2008). In South-Eastern European (SEE) countries, the second most widely applied protected area management category is category II (the first is category V) with the largest surface designated under it in Albania (Vasilijević et al. 2018).

Some of the globally most valued and recognized protected areas are designated as World Heritage Sites (WHS) and included on the World Heritage List, for which the key requirement is Outstanding Universal Value (OUV). Natural sites on this List must meet at least one out of four criteria listed from vii to $\mathrm{x}$. Each WHS provides biodiversity and geoheritage conservation benefits and contributes to the well-being of local communities and the wider human society (Osipova et al. 2014). Nevertheless, certain factors affect WHS, and these factors include built up environments (housing and transportation), social/cultural uses of heritage (tourism/ visitor/recreational activities) and climate change-related factors (humidity, natural hazards) (Galland et al. 2016).

Management objectives are those that affect the IUCN categories, which means that protected areas in category II are managed mainly for the purposes of ecosystem protection and recreation. Management planning is 
a process, not an event, and the product is a Management Plan (MP). Management Plan is defined as "a document which sets out the management approach and goals, together with a framework for decision making, to apply in the protected area over a given period of time. Management Plans should be concise documents that identify the key features or values of the protected area" (Thomas and Middleton 2003). According to the analysis of information for SEE countries, there are seven adopted management plans for national parks and nine for other protected areas in Croatia, which is far less than in Serbia with 59 protected areas, none of which, however, are national parks (Vasilijević et al. 2018).

Management Plans designate different management zones that are defined as geographical areas within which similar management is applied and similar levels of use permitted and different uses segregated. Zones are identified so that the strategies used for management will best accomplish the objective of achieving the desired future for the protected area (Thomas and Middleton 2003). The establishment of meaningful zones or compartments is based on an analysis of information derived from the management objectives and their associated rationales (Alexander 2010).

Recreational and visitor opportunities are a significant part of protected areas. Tourism in general is an important source of income for many countries and it is estimated that the revenue from international tourism reached USD 1.7 trillion in 2018 (UNWTO 2019). Tourists require beautiful natural areas, healthy wildlife and nature. However, managers of many protected areas are also expected to provide meaningful and educational experiences while at the same time avoiding compromising the environmental integrity of protected areas by overcrowding, overdevelopment or pollution, which tourism can sometimes bring (Leung et al. 2018). The potential benefits from tourism in protected areas include enhancing economic opportunity, protecting natural and cultural heritage and enhancing the quality of life. On the other hand, there are potential risks that tourism will bring financial and economic costs (increased demands for basic services), socio-cultural costs (increased congestion, littering etc.) and environmental costs (to the ecosystems, water, wildlife) (Eagles et al. 2002).

Management of visitors in protected areas has improved significantly since the 1930s, when Parks in the United States were facing challenges of increasing numbers of visitors and it was suggested that the number of people in some wilderness areas must be kept within the carrying capacity (Manning 2011). It was recognized that carrying capacity couldn't be calculated as the maximum number of visitors that an area can accept without negative effects on the area and visitor experience, but that the key questions are what are the desired social and biophysical conditions at a destination ( $\mathrm{McC}$ cool and Lime 2001). There are a number of methodological and conceptual frameworks for planning and managing more appropriate visitor use, including Recreation Opportunity Spectrum (ROS) (Clark and Stankey 1979), Limits of Acceptable Change (LAC) (Stankey et al. 1985), Visitor Impact Management (VIM) (Graefe et al. 1990) and most recently Visitor Use Management (IVUMC 2016). For managers of World Heritage sites the new Visitor Management Assessment Tool will shortly be available and will enable a rapid and efficient assessment of how tourism is being managed in terms of a set of sustainability indicators and identified strategies in order to address the priority issues (WHC 2019a).

This study describes the management zonation used in the development of the 2019-2028 Management Plan for the Plitvice Lakes National Park, which has three main objectives:

i. To compare the differences in management zonation (percentage of zones and subzones, methodology) using both Management Plans (most recent and previous one).

ii. Present the use of ROS classes in visitor management.

iii. Evaluate the effect of zonation on the Plitvice Lakes National Park as a UNESCO World Heritage Site with outstanding universal value.

\section{Plitvice Lakes National Park - site description}

This National Park is located in a mountainous part of Croatia at an average altitude of $600 \mathrm{~m}$ a.s.l. (Fig. 1). Administratively, around $91 \%$ of the Park is located within Ličko-senjska County and 9\% in Karlovačka County. There are 20 settlements within the Park. The demographic trends are unfavourable, with an aging population and emigration of young people (CBS 2011). Park area is $29,630.8$ ha with predominantly forest areas $(81 \%)$, grassland (approximately 15\%) and areas changed due to anthropogenic activity (around 3\%), while the aquatic area only makes up $1 \%$ of the surface. Plitvice Lakes National Park was designated a national park in 1949 and is the oldest protected area in Croatia.

This National Park was included on the UNESCO World Heritage List in 1979 as a natural heritage based on criteria (ii) and (iii), which nowadays correspond to criteria (vii), (viii) and (ix) (WHC 2005). The Outstanding Universal Value of the Park is defined through the beautiful and intact series of lakes formed by tufa barriers, which are the result of longstanding and ongoing interaction between water, air, sediments (geological foundation) and organisms (vii), intactness of the tufa formation phenomena as an undisturbed ongoing process (viii) and mosses, algae and bacteria contribute to the creation of these natural barriers (ix) (WHC 2019b). In 1997, the borders of the Park were extended in order to include a wider catchment area and thus enhance the integrity of the site and so safeguard the source of the water and enlarge the area of forest by including unlogged forest (IUCN-WCMC 2000).

Biological diversity in the Park is reflected in its abundant flora with over 1,400 vascular species of plants, 


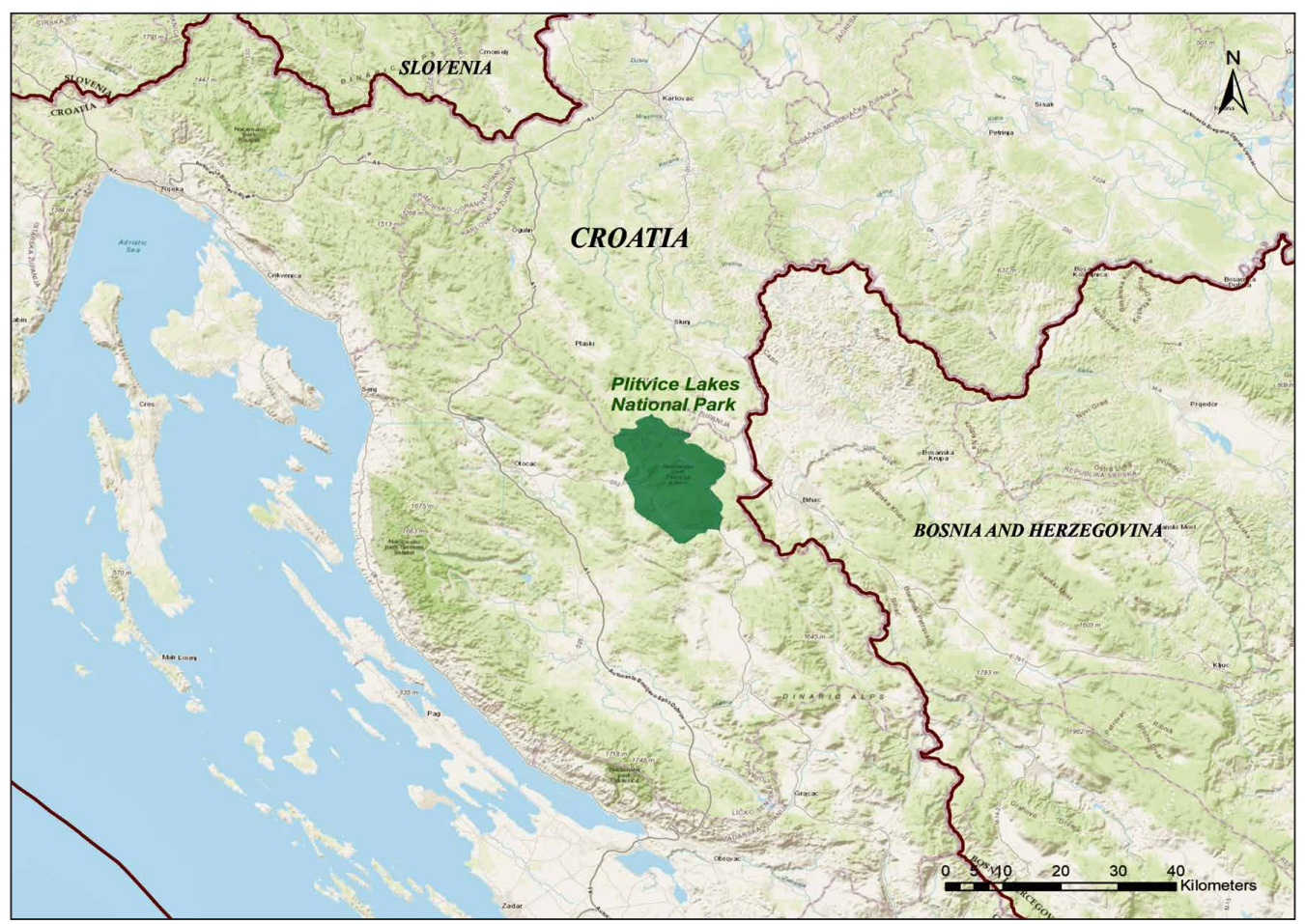

Fig. 1 Map showing the location of the Plitvice Lakes National Park in the Republic of Croatia.

including $5 \%$ of strictly protected species, as well as a rich fauna of invertebrates and vertebrates including all three large European carnivores: brown bear (Ursus arctos), wolf (Canis lupus) and lynx (Lynx lynx). There are also various types of habitats in the forest, grassland and freshwater ecosystems. The entire area of the Park is a Natura 2000 site, including 21 wild species of birds, 20 habitats and 27 wild flora and fauna species.

The National Park is managed by a Public Institution and governed by the Ministry of Environment and Energy (MEE), which makes it type A according to the IUCN category of governance (Borrini-Feyerabend et al. 2013). The Institution employs over 1,000 people during the tourist season, while there are around 600 permanent employees. This Public Institution funds its operations and activities from revenue from fees (primarily entry tickets and parking fees), sale of products and goods and provision of hotels, restaurants and other tourism services. It is estimated that slightly under 20 per cent of the Park surface is in private ownership (mainly grassland areas).

The natural beauty of the area has always been an important part of the Plitvice Lakes experience, even before the area was designated a protected area. First accommodation for visitors was built in 1862. Starting from 1893 , some of the first examples of visitor infrastructure were constructed. In the second half of the 20th century, facilities for visitors were developed further with the construction of wooden chestnut boardwalks along the lakes and across the tufa barriers, which made the visitor experience even more special. In addition, panoramic vehicles and electric boats were used to transport visi- tors round the park, but this was only sufficient for a low number of visitors. The highest number of visitors in the period between 1960 and 2000 was recorded in 1985 with 763,590 visitors (Vidaković 2003). Since 2000, the number of visitors has been constantly increasing and in 2018 the National Park was visited by $1,796,670$ visitors, who visited less than 1 per cent of the Park surface (Fig. 2).

\section{Methodology}

Methodology behind zonation can vary substantially depending on the management of each protected area; however, the natural value or biodiversity of every pro-

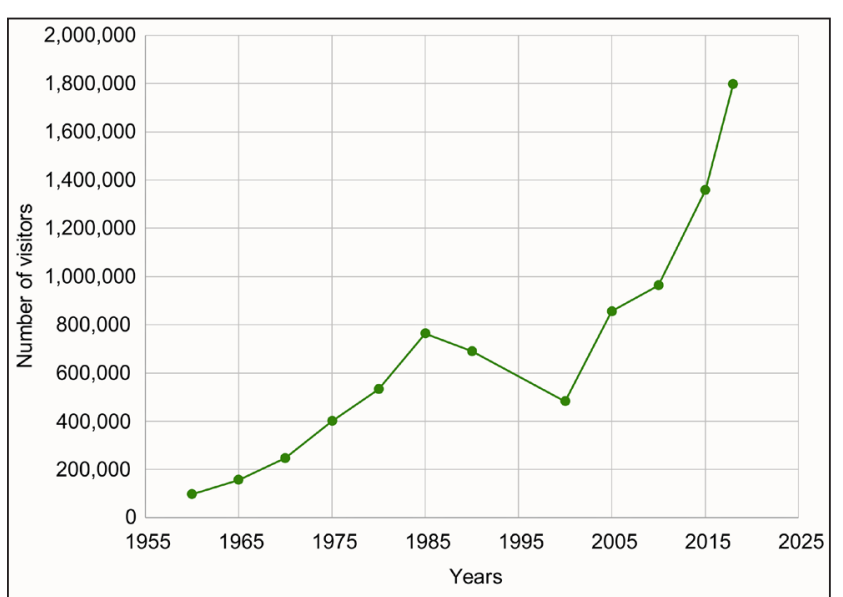

Fig. 2 Changes in the numbers of visitors over the years. Significant decrease in number was observed between 1990 and 2000 due to War and recovery of the management and the area afterwards. 
tected area is the main consideration. The process can include various ways of collecting and interpreting data, for instance satellite image data combined with field data (Newman et al. 2007), use of zoning models (Sabatini et al. 2007), Component-Process-Services (CPS) conceptual framework comparing two zoning models (Zeng et al. 2012), or weighting and ranking the priority areas (Soosairaj et al. 2007).

For the Plitvice Lakes National Park, the management zonation is based on the Guidelines for Protected Areas and/or Natura 2000 Site Management Planning (MEE and CAEN 2018). Based on the Guidelines three main zones (I, II and III), with subzones IA and IB were established. Nevertheless, each of the zoned areas does not need to have subzones, and the establishment of subzones will primarily depend on the management needs of an area (Table 1).

The zonation was defined using the ESRI program ArcMap 10.2.2 (ESRI 2014) and topography maps (TM) 25000 from the State Geodetic Administration (SGA). Furthermore, the Croatian cadastre (from SGA) was used, as well as CORINE Land Cover (CLC) that was downloaded from www.copernicus.eu/en as a foundation for Natura 2000 habitats.

The zones mainly consisted of polygons and point localities; however, points are not on the maps due to the resolution and their size. Intermittent streams were presented as polygons with $3 \mathrm{~m}$ buffer in order to enable surface calculations, while permanent streams were vectored using orthophoto (taken in 2018) and Light Detection and Ranging (LIDAR, from 2014). State and county roads in subzone IIIB were determined to be $12 \mathrm{~m}$ wide and local roads $8 \mathrm{~m}$ wide, for the purposes of accurate surface calculations.
The objectives of visitor-use in the new Management Plan were specified using the ROS classes that describe a spectrum of opportunities for visitor experience that the Park can offer. In line with the ROS framework, each of the classes in the spectrum is described by:

- Key elements of experience;

- Biophysical, social and managerial conditions required for the targeted visitor experience;

- Set of indicators, i.e., measurable variables used to monitor the fulfilment of the required conditions;

- Set of standards, i.e., threshold values of indicators for which required conditions are considered fulfilled.

According to the ROS methodology, recreational setting is specified and determined by three types of attributes (biophysical, social and managerial), each varying along a continuum from none to a lot (e.g. from pristine natural environment with no anthropogenic changes to highly modified environments; from none or few to many and frequent encounters with other visitors; etc.). Several ROS classes were identified, each of which were defined by a combination of attributes, appropriate for targeted visitor experience. They ranged from primitive to modern, while biophysical, social and managerial conditions varied depending on the class (Fig. 3).

Based on the inventory of the values and opportunities for visitors in the PLNP, as well as sensitivity of particular areas within the Park to the pressures that could result from visitors, the following ROS classes were defined:

- Park areas not open to visitors (zone of prohibited independent entry);

- Class I (direct experience of pristine wilderness with high level of self-reliance);

- Class II (direct experience of conserved nature with medium level of self-reliance);

Table 1 Descriptions of zones and the colours recommended for use in mapping the zones (adopted from MEE and CAEN 2018).

\begin{tabular}{|c|c|c|c|}
\hline Zone name & Subzone/Zone & Colour & \multirow{3}{*}{$\begin{array}{l}\text { Description } \\
\text { Areas of natural ecosystems, where habitat conservation status has not } \\
\text { changed due to human impact and active management measures are not } \\
\text { needed for conservation. } \\
\text { Management objective: conservation of natural processes and ecosystem } \\
\text { naturalness. } \\
\text { Guidelines allowing: research, monitoring or surveillance, emergency inter- } \\
\text { ventions (fire, eradication of invasive species) and limited visitation. }\end{array}$} \\
\hline \multirow[b]{2}{*}{$\begin{array}{l}\text { Strict } \\
\text { Conservation } \\
\text { Zone }\end{array}$} & IA & Dark green & \\
\hline & IB & Light green & \\
\hline $\begin{array}{l}\text { Active } \\
\text { Management } \\
\text { Zone }\end{array}$ & ॥ & Yellow & $\begin{array}{l}\text { Semi-natural ecosystems, geo-localities and cultural landscape areas that } \\
\text { require the implementation of active management measures concerning } \\
\text { conservation or restoration. } \\
\text { Areas where human presence has resulted in ecosystem changes, in history } \\
\text { or recent times. } \\
\text { Management objective: conservation and/or improvement of the status of } \\
\text { biodiversity, geodiversity and cultural landscape. } \\
\text { Guidelines allowing: research, monitoring, surveillance and implementa- } \\
\text { tion of active measures focused on conservation, visitation, establishment } \\
\text { of minimal interpretation and education content and access trails that do } \\
\text { not require maintenance. }\end{array}$ \\
\hline $\begin{array}{l}\text { Sustainable } \\
\text { Use Zone }\end{array}$ & III & Purple & $\begin{array}{l}\text { Areas where nature is substantially changed due to the presence of a cer- } \\
\text { tain degree of use. } \\
\text { Management objective: sustainability of present and planned usage of } \\
\text { space, in accordance with protected area management objectives. }\end{array}$ \\
\hline
\end{tabular}

European Journal of Environmental Sciences, Vol. 9, №. 2 


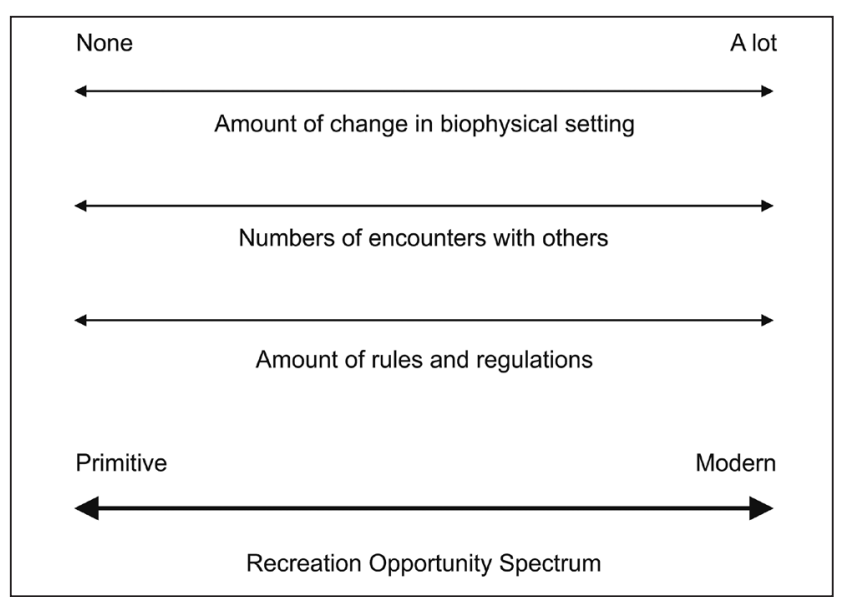

Fig. 3 The Recreation Opportunity Spectrum (adapted from McCool et al. 2007).

- Class III (experience of freshwater ecosystem and opportunity to actively experience Outstanding Universal Value of the Park with low level of self-reliance);

- Class IV (experience of the ambience of traditional settlements and architecture with the possibility of purchasing local products and learning about the cultural heritage);

- Class V (entrances into the Park and tourism services).

\section{Results}

In accordance with the characteristics of the area and management needs, all of the 3 main zones with additional division into subzones were determined (Table 2). The highest percentage of the Park (80.7\%) is situated in the Strict Conservation Zone (Zone I); $17.1 \%$ in the Active Management Zone (Zone II) and $2.2 \%$ in the Sustainable Use Zone (Zone III).

Table 2 Management zones and subzones defined in the PLNP Management Plan 2019-2028.

\begin{tabular}{|c|c|c|c|}
\hline \multicolumn{2}{|c|}{ Zone } & \multicolumn{2}{|c|}{ Subzone } \\
\hline \multirow{2}{*}{ I } & \multirow{2}{*}{$\begin{array}{l}\text { Strict Conservation } \\
\text { Zone }\end{array}$} & IA & No visitation \\
\hline & & IB & With limited visitation \\
\hline \multirow{3}{*}{ II } & \multirow{3}{*}{$\begin{array}{l}\text { Active Management } \\
\text { Zone }\end{array}$} & $\| \mathrm{A}$ & Aquatic ecosystems \\
\hline & & IIB & Grasslands, fens and bogs \\
\hline & & IIC & Cultural landscape \\
\hline \multirow{4}{*}{ III } & \multirow{4}{*}{ Sustainable Use Zone } & IIIA & Settlement areas \\
\hline & & IIIB & Roads \\
\hline & & IIIC & $\begin{array}{l}\text { Built areas with services for } \\
\text { visitors }\end{array}$ \\
\hline & & IIII & $\begin{array}{l}\text { Paths, roads and docks man- } \\
\text { aged by the Public Institution }\end{array}$ \\
\hline
\end{tabular}

Strict Conservation Zone encompasses areas of natural ecosystems the characteristics and habitat conservation status of which have not been changed by human ac- tivities and active management measures are not needed for their conservation. This includes areas of ecosystems that have been changed by human activities but are now recovering naturally. Active management is not needed for the recovery of these areas other than to protect them from human pressure. In line with the Guidelines (MEE and CAEN 2018), the Strict Conservation Zone (Zone I) was further divided into two subzones (Fig. 4a), with the main difference being that in subzone IA visitation is not allowed, while in subzone IB limited low intensity and targeted visitor use is allowed, but only under the supervision and guidance of the Public Institution. Significant changes in the areas of these subzones in Park were recorded, with subzone IB increasing by $53.8 \%$ relative to subzone IA. The subzone IB includes forest areas, whereas subzone IA includes the best-conserved natural habitats in the Park (old-growth beech-fir forests (Čorkova uvala), localities of the lady's slipper orchid (Cypripedium calceolus), caves and pits, canyon of the river Korana, etc.).

Active Management Zone includes semi-natural ecosystems, geolocalities and cultural landscape areas that need to be actively managed in terms of conservation or restoration for the purpose of long-term conservation. This zone includes areas where human presence has resulted in changes in the ecosystem, historically or recently, and conservation of the biodiversity there requires active management. Active Management Zone (Zone II) consists of three subzones (Fig. 4b). Subzone IIA includes the entire lake system, tufa barriers, most of permanent watercourses, and small aquatic habitats: ponds, wells and wetland. This subzone covers less than $1 \%$ of the Park surface. The active management here is focused on the conservation of aquatic ecosystems and key processes (tufa formation), in order to mitigate current anthropogenic effects (e.g. of visitors in the lake area) and/or consequences of previous interventions (e.g. dams, barriers on watercourses etc.). The management measures include the prevention of succession and eutrophication, restoration of habitats for the purposes of conservation of individual species (e.g. brown trout) and possible substantial interventions in space.

Subzone IIB (14.8\% of Park surface) includes grasslands, fens, bogs, forest clearings and forested areas along forest roads and paths, including forest areas located within the subzone IB registered as meadows or pastures. Active management is focused on conserving the biodiversity of grasslands, fens and bogs (e.g. by stopping succession) and on restoration of substantially changed habitats of Natura 2000 species or other significant species.

Subzone IIC (1.4\% of Park surface) includes human-conditioned traditional landscape around settlements with valuable natural and semi-natural habitats (gardens, crofts, meadows and pastures). Management here includes active management of natural and semi-natural habitats aimed at conserving biodiversity and restoring substantially changed habitats. 


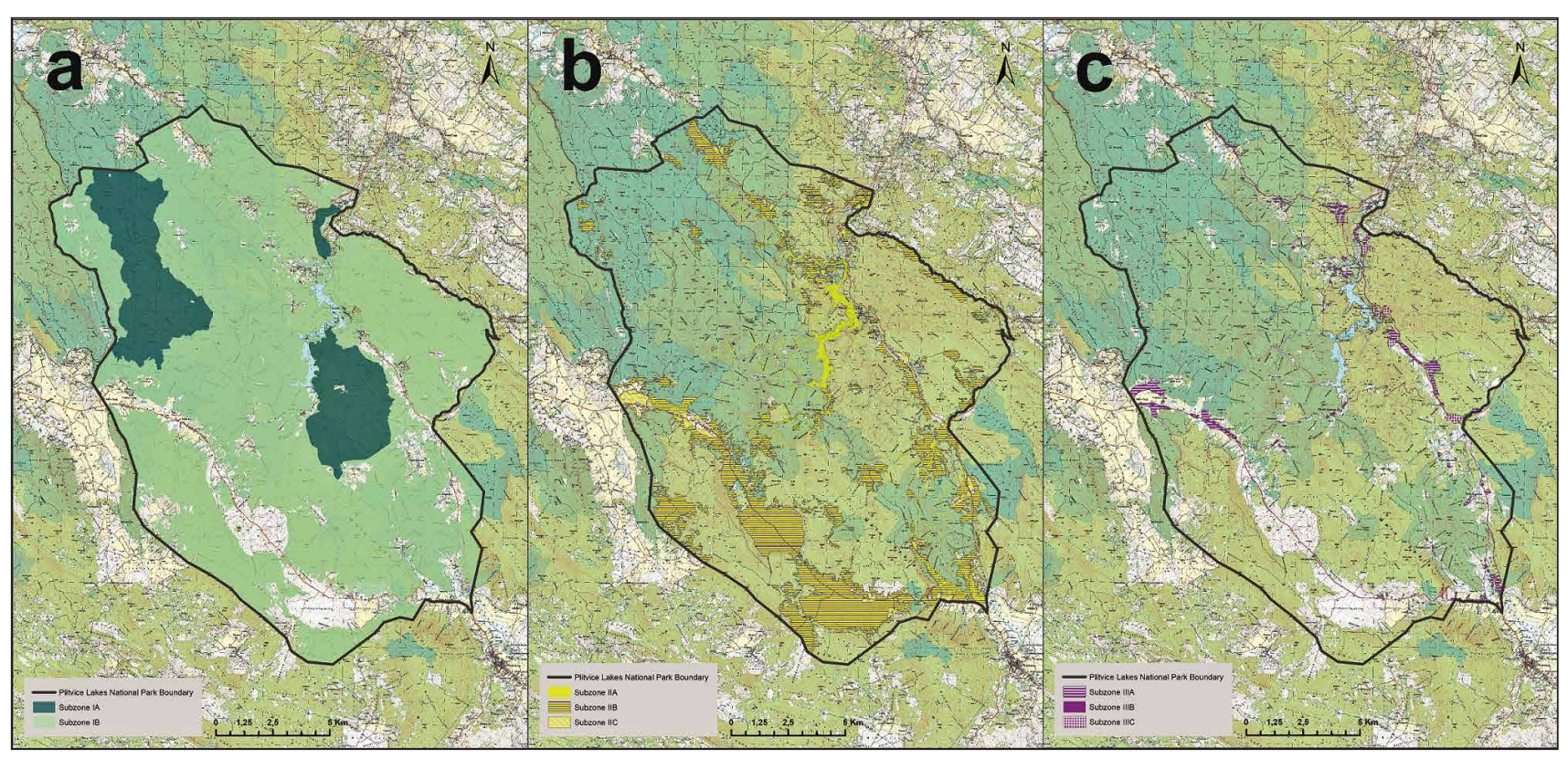

Fig. 4 Map showing the subzones in: a) Strict Conservation Zone, b) Active Management Zone and c) Sustainable Use Zone.

Sustainable Use Zone includes areas where nature has been substantially changed due to use and those designated as the most favourable localities for various permitted forms of high-intensity use, in accordance with the conservation objectives in this zone, which is a compromise between nature conservation and usage. Sustainable Use Zone (Zone III) was further divided into four subzones. In subzone IIIA (Settlements) (Fig. 4c) the primary objective is to ensure adherence to all legal provisions and prescribed nature conservation requirements that prevent settlements and construction in the Park having negative effects on the ecosystems and landscape (e.g. adequate water supply and wastewater treatment, new construction, etc.). Furthermore, every settlement and inhabited area in the immediate vicinity of watercourses must be planned with particular care and situated at least 200 meters away from riverbanks and lake shores.

Subzone IIIB includes all roads within the Park, while the subzone IIIC includes the paths and trails for visitors that require regular maintenance. Subzone IIID includes built up areas outside settlements, with services for visitors (entrances, hotels, restaurants). Management in these subzones is focused on maintenance or reconstruction of existing infrastructure with the purpose of securing the services and security for visitors (installation of fences, removal of trees, etc.), while mitigating the negative effect on ecosystems and landscape. All infrastructure managed by the Public Institution must fulfill the highest energy and environmental efficiency standards.

Management zonation is a decision-making process and its complexity is described in a more detailed map of the area of the Park, with all subzones indicated (Fig. 5). In respect of the special management conditions for each subzone (species, habitats, Natura 2000 sites, etc.), the overlaps had to be consistent and it was not permitted to exclude a single subzone even if it intersects another subzone. The polygon of subzone IA intersects that of subzone IIIB (county road), subzone IIID (forest road) and polygon of subzone IIB. A good example of a different management approach in connection with subzones is evident for subzone IIA (lake area) that intersects subzone IIID (trails).

The comparison of the two Management Plans (previous and recent) reveals not only the changes in zone names, but significant changes in the divisions into subzones and their share of the Park surface. Compared to the previous MP (Šikić 2007a) the Strict Conservation Zone has significantly increased by $13.9 \%$ in the new MP. Other significant changes have occurred in Zones II and III. There were only two subzones of Zones II and III in the previous MP, whereas there are three subzones of Zone II and four of Zone III in the new MP. In the new

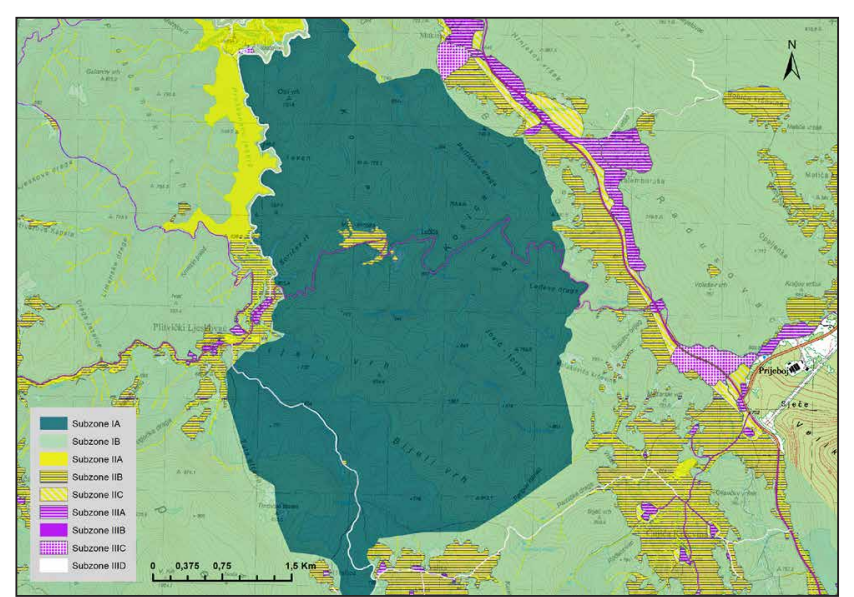

Fig. 5 Detailed map showing the management zones and their subzones of a small area of the PLNP. 
Table 3 Comparison of the areas (in ha and \%) of the management zones and subzones in previous (2007-2017) and recent (2019-2028) Management Plans.

\begin{tabular}{|c|c|c|c|c|c|c|c|c|c|c|c|}
\hline \multicolumn{6}{|c|}{ PLNP MANAGEMENT PLAN 2007-2017 } & \multicolumn{6}{|c|}{ PLNP MANAGEMENT PLAN 2019-2028 } \\
\hline \multicolumn{2}{|r|}{ Zone } & \multicolumn{2}{|r|}{ Subzone } & \multirow{2}{*}{$\begin{array}{r}\begin{array}{c}\text { Surface } \\
\text { (ha) }\end{array} \\
2,480\end{array}$} & \multirow{2}{*}{$\begin{array}{c}\begin{array}{c}\text { Share } \\
\text { in Park } \\
\text { surface } \\
(\%)\end{array} \\
8.4\end{array}$} & \multicolumn{2}{|r|}{ Zone } & \multicolumn{2}{|r|}{ Subzone } & \multirow{2}{*}{$\begin{array}{c}\begin{array}{c}\text { Surface } \\
\text { (ha) }\end{array} \\
3,986.9\end{array}$} & \multirow{2}{*}{ 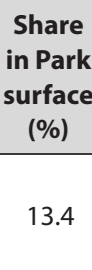 } \\
\hline \multirow{3}{*}{ I } & \multirow{3}{*}{$\begin{array}{l}\text { Strict } \\
\text { Conservation } \\
\text { Zone }\end{array}$} & IA & $\begin{array}{l}\text { Strictest } \\
\text { Conservation } \\
\text { Zone }\end{array}$ & & & \multirow{3}{*}{1} & \multirow{3}{*}{$\begin{array}{l}\text { Strict } \\
\text { Conservation } \\
\text { Zone }\end{array}$} & IA & No visitation & & \\
\hline & & IB & $\begin{array}{l}\text { Very strict } \\
\text { conservation } \\
\text { zone }\end{array}$ & 17,281 & 58.4 & & & IB & With limited visitation & $19,934.8$ & 67.3 \\
\hline & & \multicolumn{2}{|c|}{ Total for Zone I } & 19,761 & 66.8 & & & \multicolumn{2}{|c|}{ Total for Zone I } & $23,921.7$ & 80.7 \\
\hline \multirow{3}{*}{ II } & \multirow{3}{*}{$\begin{array}{l}\text { Active } \\
\text { Conservation } \\
\text { Zone }\end{array}$} & $\| A$ & $\begin{array}{l}\text { Active habitat } \\
\text { conservation } \\
\text { zone }\end{array}$ & 6,729 & 22.7 & \multirow{3}{*}{ II } & \multirow{3}{*}{$\begin{array}{l}\text { Active } \\
\text { Management } \\
\text { Zone }\end{array}$} & $\| \mathrm{A}$ & Aquatic ecosystem & 278.3 & 0.9 \\
\hline & & IIB & $\begin{array}{l}\text { Active forest } \\
\text { ecosystem } \\
\text { conservation zone }\end{array}$ & 2,619 & 8.8 & & & IIB & $\begin{array}{l}\text { Grasslands, } \\
\text { fens and bogs }\end{array}$ & $4,384.5$ & 14.8 \\
\hline & & \multicolumn{2}{|c|}{ Total for Zone II } & 9,348 & 32.5 & & & \multicolumn{2}{|c|}{ Total for Zone II } & $5,067.8$ & 17.1 \\
\hline \multirow{5}{*}{ III } & \multirow{5}{*}{$\begin{array}{l}\text { Usage } \\
\text { Zone }\end{array}$} & IIIA & Settlement zone & 226 & 0.8 & & \multirow{5}{*}{$\begin{array}{l}\text { Sustainable } \\
\text { Use Zone }\end{array}$} & IIIA & Settlement areas & 375.6 & 1.3 \\
\hline & & \multirow{3}{*}{ IIIB } & \multirow{3}{*}{$\begin{array}{l}\text { Recreation } \\
\text { and tourism } \\
\text { infrastructure } \\
\text { zone }\end{array}$} & \multirow{3}{*}{227} & \multirow{3}{*}{0.9} & \multirow{4}{*}{ III } & & IIIB & Roads & 115.3 & 0.4 \\
\hline & & & & & & & & IIIC & $\begin{array}{l}\text { Built areas with services } \\
\text { for visitors }\end{array}$ & 79.3 & 0.3 \\
\hline & & & & & & & & IIID & $\begin{array}{l}\text { Paths, roads and docks } \\
\text { managed by the Public } \\
\text { Institution }\end{array}$ & 71.1 & 0.2 \\
\hline & & Tota & I for Zone III & 503 & 1.7 & & & Tota & for Zone III & 641.3 & 2.2 \\
\hline & ERALL & & & 29,612 & 100 & OV & EALL & & & $29,630.8$ & 100 \\
\hline
\end{tabular}

MP there is a significant decrease of $15.4 \%$ in the share of Park surface in the case of Zone II and 0.5\% increase in Zone III (Table 3). In addition, the difference in overall Park surface in the two MPs is clear.

Allocation of ROS classes (Fig. 6) for Zone of prohibited independent entry overlapped the Strict Conservation Zone (IA), with the addition of the Vrelske bare locality, which is in the subzone IIB (sensitive grassland habitat that requires active management). Class I and Class II overlapped subzone IB (mainly forest areas), with existing and planned hiking trails belonging to management subzone IIID. The main difference between them is that Class I includes more remote and less frequently visited areas than Class II. Class III overlapped subzone IIA area of the lakes, while Class IV includes traditional settlements without significant development of tourist infrastructure. Class V includes urbanized areas with visitor facilities.

\section{Discussion}

Long-term vision and general objectives of the Management Plan, as well as specific objectives and their in- dicators, define the basic policies of Park management. The previous Management Plan that was adopted in 2007 significantly deviated from ideal planning and was of very limited use in operative planning. This weakness in management was recognized in the recent IUCN World Heritage Outlook report where the National Park was assessed as having deteriorated in terms of its status from good status with some concerns to status of significant concern due to increasing housing development that caters for the ever increasing numbers of visitors. Furthermore, while the ecological values of the site has so far been preserved, protection and management have moved from effective in 2014 to some concern in 2017 (Osipova et al. 2017). Therefore, the adoption of the new MP, including the new zonation, could not have come at a better time.

The most marked difference between the previous and new management zonation is the designation of new subzones within Zones II and III, which is more in line with the management objectives. The difference in overall Park surface in the MPs was a result of incorrect calculations of the total Park surface and its border in the previous MP. However, the Park border and surface was recalculated, and the official Park surface is now 29,630.8 ha. 


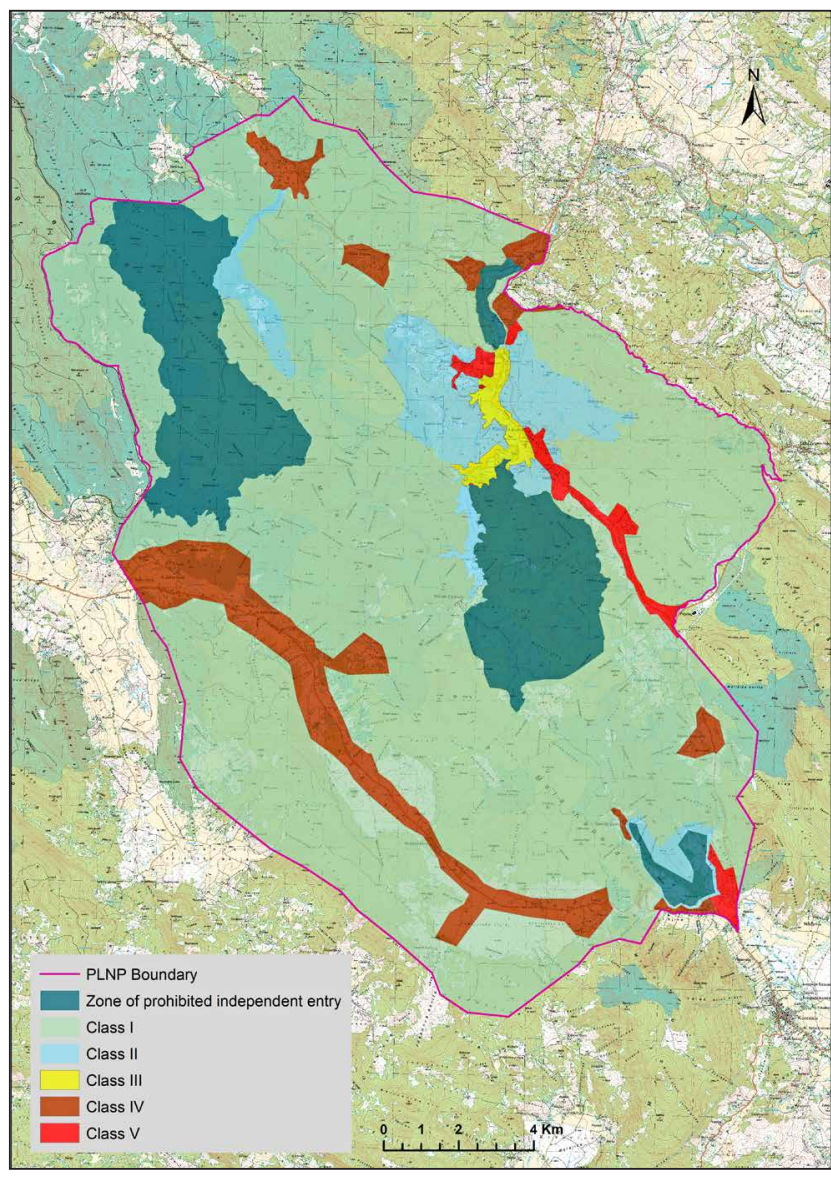

Fig. 6 Map showing the allocation of ROS classes within the Plitvice Lakes National Park.

There are significant changes in the shares of the Park surface in zones and subzones. The highest difference is in Zone II, which was larger in the previous Plan due to subzone IIB, i.e., Active Forest Ecosystem Conservation Zone. In the new zonation, almost the entire former subzone IIB is now included in subzone IB, consequently increasing Zone I. The previous zonation was developed on the basis of the guidelines of the Karst Ecosystem Conservation project, which resulted in the adoption of several MPs for protected areas, including Risnjak, Paklenica and Sjeverni Velebit National Parks. Zonation of Risnjak National Park included the same division into zones and subzones as the PLNP zonation. By comparing the situation with subzone IIB in previous MPs for both Parks, it is concluded that the active forest ecosystem zone implied possible forestry activities such as sanitary logging (Šikić 2007b) while permitted activities in case of PLNP were connected with degraded forest (Šikić 2007a). However, the new concept of management of forest ecosystems in the Park is focused on leaving the forest to natural development, which is the appropriate conservation measures for Natura 2000 habitats.

Increased share of Zone I and decreased share of Zone II of the total Park surface can be explained by succession and loss of grassland to forest. This is addressed in zonation by including all Natura 2000 grasslands in subzone
IIB, which requires active management to prevent succession. Furthermore, this Public Institution has the policy of purchasing real estate within Park boundaries from private owners, and this primarily includes agricultural and forest land. This significant activity enables the Park management to actively manage protected habitats, especially grasslands. Grasslands, mires and bogs are reported to be the most degraded habitats across Europe and Central Asia and the biodiversity in temperate grasslands in Eastern Europe exhibit a variable trend in biodiversity (Fischer et al. 2018).

The major difference between the two plans is the transfer of sensitive and unique area around the lakes, with the most prominent OUV, from subzone IIIB (use) to the subzone IIA (active management). This transfer reflects the imperative of conservation, even in the most visited areas.

Zone III was enlarged due to inclusion of roads, which were not included in the previous MP zonation. Paths and hiking trails that are a part of the visitor system are now included in subzone IIID.

This more thorough zonation unlike the previous one opened up more opportunities for better area management. That was not the case for the Šumava National Park (Czech Republic), where Zone I was reduced and Zone II enlarged due to logging (Křenová and Hruška 2012). However, the National Park of Abruzzo (Italy) aimed to increase its Strict Reserve Zone from 6.9\% to $14-15 \%$ even though the areas to be included do not match the IUCN Protected Area categories (Synge 2004).

Authors McCool and Eagles (2014) recommended PLNP take action and develop a visitor management strategy using ROS methodology. The rationale behind this recommendation was the lack of visitor and tourism management policy in the previous MP. Classification using ROS resulted in the development of classes that were closely in line with the management zonation. Therefore, the establishment of biophysical, social and managerial conditions with their indicators and standards had to be performed with caution, in order to avoid possible inconsistency in further management or decision-making processes. Attention was drawn to the Zone of Prohibited Entry, which was not only allocated to Zone I but also to Zone II in the management zonation. Even though Zone II implies a certain number of visitors, conservation measures were more important in the case of this ROS class. In addition, for the purposes of interpretation of this specific zone, particular in its border areas, Class II was designated based on biophysical conditions determined by hiking trails and trail markings, information and interpretation content. The number of visitors to Class I areas is determined by the use of hiking trails which are in subzone IIID; however, social conditions are such that there is a small probability of encountering other people, while Class II implies the possibility of occasional encounters. Even though the ROS methodology has not been used for Hohe Tauren National Park (Austria), their approach to visitor management is 
to balance the wishes and expectation of visitors with the need to conserve nature (Synge 2004). For the protected areas in Turkey, it is recognized that long-term development plans are not user-oriented and do not include visitor management (Duzgunes and Demirel 2016).

\section{Conclusions}

Management zonation reflects the need to manage the Park in terms of conserving its specific biodiversity, geodiversity and Outstanding Universal Value. It was designated based on available spatial and other relevant data regarding Natura 2000 and other significant species and habitats and their ecological requirements, significant geo-localities, cultural values, visitor experience opportunities and existing and planned infrastructure and settlements. Significant increase in the area in the Strict Conservation Zone is evident, which is a contribution to Aichi Target 11 (CBD 2010).

ROS methodology provided a completely new spectrum of visitor opportunities that enabled the Park management to adopt a new approach to visitor management (together with other visitor-use measures).

The presented management zonation should facilitate the Park management to achieve the vision of Plitvice Lakes National Park as a UNESCO World Natural Heritage Site, a place to experience and learn about the Outstanding Universal Value and other natural and cultural values, with good protected area management in cooperation with the local community, where conserved nature is the foundation of sustainable development.

\section{REFERENCES}

Alexander M (2010) A Management Planning Guide. CMS Consortium, Talgarth, Wales, UK.

Belle E, Kingston N, Burgess N, Sandwith T, Ali N, MacKinnon K (eds) (2018) Protected Planet Report 2018. UNEP-WCMC, IUCN and NGS: Cambridge UK, Gland Switzerland and Washington D.C. USA.

Borrini-Feyerabend G, Dudley N, Jaeger T, Lassen B, Pathak Broome N, Phillips A, Sandwith T (2013) Governance of Protected Areas: From Understanding to Action. Best Practice Protected Area Guidelines Series No. 20. Gland, Switzerland, IUCN.

Clark R, Stankey G (1979) The Recreation Opportunity Spectrum: A Framework for Planning, Management and Research. USDA Forest Service, General Technical Report PNW-98.

Convention on Biological Diversity (CBD) (2010) Decision X/2: Strategic Plan for Biodiversity 2011-2020. UNEP/CBD/COP/ $\mathrm{DEC} / \mathrm{X} / 2$, Nagoya, Japan.

Croatian Agency for Environment and Nature (CAEN) (2019) Protected areas in Croatia. CAENWeb. http://www.haop.hr /hr/tematska-podrucja/zasticena-podrucja/zasticena-podrucja /zasticena-podrucja-u-rh.

Croatian Bureau of Statistics (CBS) (2011) The Census of Population, Households and Dwellings in the Republic of Croatia in
2011. CBSWeb. https://www.dzs.hr/Eng/censuses/census2011 /censuslogo.htm

Dudley N (ed) (2008) Guidelines for Applying Protected Area Management Categories. Gland, Switzerland, IUCN.

Duzgunes E, Demirel O (2016) Importance of visitor management in national park planning. J Environ Prot Ecol 17: 675-680.

Eagles PFJ, McCool SF, Haynes CDA (2002) Sustainable Tourism in Protected Areas: Guidelines for Planning and Management. IUCN Gland, Switzerland and Cambridge, UK.

Environmental Systems Research Institute (ESRI) (2014) ArcGIS Release 10.2.2 Redlands, CA.

Fischer M, Rounsevell M, Torre-Marin Rando A, Mader A, Church A, Elbakidze M, Elias V, Hahn T, Harrison PA, Hauck J, Martín-López B, Ring I, Sandström C, Sousa Pinto I, Visconti P, Zimmermann NE, Christie M (eds) (2018) Summary for policymakers of the regional assessment report on biodiversity and ecosystem services for Europe and Central Asia of the Intergovernmental Science-Policy Platform on Biodiversity and Ecosystem Services. IPBES secretariat, Bonn, Germany.

Galland P, Lisitzin K, Oudaille-Diethardt A, Young C (2016) World Heritage in Europe. Paris, France, UNESCO.

Graefe A, Kuss F, Vaske J (1990) Visitor Impact Management: The Planning Framework. Washington, DC: National Parks and Conservation Association.

International Union for Conservation of Nature-World Conservation Monitoring Centre (IUCN-WCMC) (2000) World Heritage Nomination - IUCN Technical Evaluation Plitvice Lakes Extension (Croatia), pp 99-105.

Interagency Visitor Use Management Council (IVUMC) (2016) Visitor Use Management Framework: A Guide to Providing Sustainable Outdoor Recreation. Edition One.

Kř̌nová Z, Hruška J (2012) Proper zonation - an essential tool for the future conservation of Šumava National Park. Eur J Environ Sci 2: 62-72, https://doi.org/10.14712/23361964.2015.40.

Leung YF, Spenceley A, Hvenegaard G, Buckley R (eds) (2018) Tourism and Visitor Management in Protected Areas: Guidelines for sustainability. Best Practice Protected Area Guidelines Series No. 27, Gland, Switzerland, IUCN.

Manning RE (2011) Studies in outdoor recreation: search and research for satisfaction. Oregon State University Press, Corvallis.

McCool SF, Lime DW (2001) Tourism Carrying Capacity: Tempting Fantasy or Useful Reality? J Sustain Tour 9: 372-388, http:// dx.doi.org/10.1080/09669580108667409.

McCool SF, Clark RN, Stankey GH (2007) An assessment of frameworks useful for public land recreation planning. General Technical Report PNW-GTR-705, Portland, OR: U.S. Department of Agriculture, Forest Service, Pacific Northwest Research Station.

McCool SF, Eagles PFJ (2014) An Assessment of Visitor and Tourism Management in Plitvice Lakes National Park and World Heritage Site, Croatia. Missoula, Montana, USA and Waterloo, Ontario, Canada.

Ministry of Environment and Energy (MEE) and Croatian Agency for Environment and Nature (CAEN) (2018) Guidelines for protected areas and/or Natura 2000 sites management planning. UNDP, Croatia. Unofficial translation in English.

Nature Conservation Act (Official Gazette of Republic of Croatia 80/13, 15/18), (in Croatian).

Newman CM, Knudby AJ, LeDrew EF (2007) Assessing the effect of management zonation on live coral cover using multi-date IKONOS satellite imagery. J Appl Remote Sens 1: 011504, https://doi.org/10.1117/1.2822612.

Osipova E, Shadie P, Zwahlen C, Osti M, Shi Y, Kormos C, Bertzky B, Murai M, Van Merm R, Badman T (2017) IUCN World Her- 
itage Outlook 2: A conservation assessment of all natural World Heritage sites. Gland, Switzerland, IUCN.

Osipova E, Wilson L, Blaney R, Shi Y, Fancourt M, Strubel M, Salvaterra T, Brown C, Verschuuren B (2014) The benefits of natural World Heritage: Identifying and assessing ecosystem services and benefits provided by the world's most iconic natural places. Gland, Switzerland, IUCN.

Sabatini M, Verdiell A, Rodríguez Iglesias RM, Vidal M (2007) A quantitative method for zoning of protected areas and its spatial ecological implications. J Environ Manage 83: 198-206, https://doi.org/10.1016/j.jenvman.2006.02.005.

Soosairaj S, Britto SJ, Balaguru B, Nagamurugan N, Natarajan D (2007) Zonation of conservation priority sites for effective management of tropical forests in India: A value-based conservation approach. Appl Ecol Env Res 5: 37-48.

Stankey GH, Cole DN, Lucas RC, Peterson ME, Frissell SS (1985) The Limits of Acceptable Change (LAC) Systems for Wilderness Planning. USDA Forest Service General Technical Report INT-176.

Synge H (2004) European Models of Good Practice in Protected Areas. Gland, Switzerland IUCN, Cambridge, UK and the Austrian Federal Ministry of Agriculture, Forestry, Environment and Water Management.

Šikić Z (ed) (2007a) Plitvice Lakes National Park Management Plan. Ministry of Culture Republic of Croatia, Plitvička Jezera, Croatia, (in Croatian).

Šikić Z (ed) (2007b) Risnjak National Park Management Plan. Ministry of Culture Republic of Croatia, Crni Lug, Croatia, (in Croatian).
Thomas L, Middleton J (2003) Guidelines for Management Planning of Protected Areas. IUCN Gland, Switzerland and Cambridge.

United Nations World Tourism Organization (UNWTO) (2019) News. Issue 87, June 2019 UNWTOWeb. http://www2.unwto .org/press-release/2019-06-06/exports-international-tourism -hit-usd-17-trillion.

Vasilijević M, Pokrajac S, Erg B (eds) (2018) State of nature conservation systems in South-Eastern Europe. Gland, Switzerland and Belgrade, Serbia, IUCN, https://doi.org/10.2305/IUCN .CH.2018.19.en.

Vidaković P (2003) Financiranje Nacionalnih parkova. In: Meštrović Š (ed) Nacionalni Parkovi i zaštićena područja u Hrvatskoj. Fond za stipendiranje mladih za zaštitu prirode i turizam Zagreb 1990, Zagreb, Croatia, pp 321-322, (in Croatian).

Zeng Q, Zhang Y, Jia Y, Jiao S, Feng D, Bridgewater P, Lei G (2012) Zoning for management in wetland nature reserves: a case study using Wuliangsuhai Nature Reserve, China. SpringerPlus 1: 1-10, https://doi.org/10.1186/2193-1801-1-23.

World Database on Protected Areas (WDPA) (2019) Protected planet. WDPA updates in 2019 WDPAWeb. https://www .protectedplanet.net/c/monthly-updates/2019/june-2019 -update-of-the-wdpa.

World Heritage Committee (WHC) (2005) Operational Guidelines for the Implementation of the World Heritage Convention. WHC.05/2.

World Heritage Committee (WHC) (2019a) State of conservation of World Heritage properties. WHC/19/43.COM/7.

World Heritage Committee (WHC) (2019b) Adoption of retrospective Statements of Outstanding Universal Value. WHC/19/43.COM/8E. 